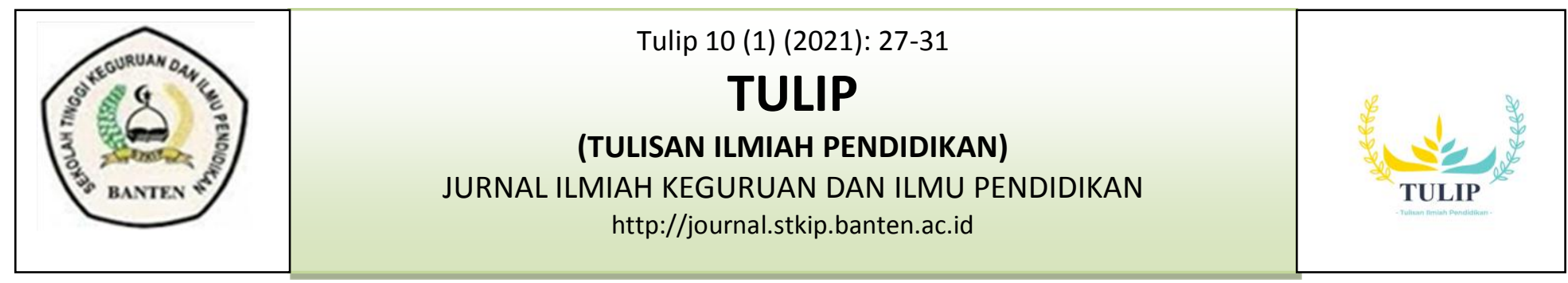

\title{
THE INFLUENCE OF MOVIE TOWARD TO STUDENTS' WRITING SKILL NARRATIVE TEXT
}

\author{
Yaser Arafat \\ School of Teacher Trainingand Education of Banten \\ arafatyaser@gmail.com
}

Artikel Movie

Penerima: Desember, 2020

Diterima: Januari, 2021

Dipublikasikan: Maret, 2021

\begin{abstract}
The background of the study in this research is based on the phonemena that student have difficulty in writing narrative text. Students could not describing thing, place, and person detail because the student don't have ideas when they are asked to describe thing, place and person. So they need some ways, method or aids which could help them in writing narrative text. Movie media is one of ways that can be used in teaching writing descriptive text. The problem of this research can be stated that how is the implementation influence of movie toward to students' writing skill narrative text. Its purpose are firstly to know the improvement of students ability in writing skill narrative text. The second is to find out how the use the movie contributes to student improvement in writing skill narrative text. So student are more active and interested in learning writing activities in class, especially the are happy with the application of learning methods to improve their writing skill by using Movie.
\end{abstract}

Key Word: Writing skill, Narrative text, Movie

\section{INTRODUCTION}

Writing is a creative process of expressing ideas in the form of written language in a goal for example telling, convincing, or entertaining. ${ }^{1}$ Next, writing can be an effective tool for the development of academic language proficiency as learners have to explore advanced lexical or syntactic expression in their written work. The last is writing across the curriculum that can be invaluable for mastering diverse subject matter. Therefore, it can be said that writing is the primary basis upon which our work and study will be judged in school or college, in the workplace, and in the community.

Moreover, the problems can arise for some students in writing because it is a complex skill involving multiple processes and abilities. Tan stated that writing is a complicated activity in cognitive analysis and linguistic synthesis in a language.

For the students learning English 
writing is important because it helps developing students' critical thinking skills and helps them to understand and to communicate complicated ideas. Therefore, they are supposed to focus on the mastery of the content of the text and to express the meaning in functional written texts and short essay from simple to complex sentences in the form of recount and narrative to interact with the surrounding environment.

Besides that, the objective of teaching writing in narrative text for the eighth grade is to help students be able to write short essay in narrative with the right steps. Furthermore, in the standard writing for the eighth grade students, it has to develop students' grammar, vocabulary, punctuation, and spelling. However, the eighth grade students have difficulties in writing so that their writing score is low although their school has complete facilitations.

From the background of the study written above, the researcher identifies problems as below:

The students have difficulty in knowing how to organize their ideas, events, and experiences.

The students have difficulties in planning, writing and revising text.

The student have difficulties with the mechanical aspect of writing such as hand writing punctuation and spelling.

The teachers have difficult to teach writing because writing is a process of communicating and still use conventional teaching to teach English.

In the research limited the problem only on influence of movie toward to students' writing skill narrative text.

Based The formulation of problem in this research is how can influence of movie toward to students' writing skill narrative text.

The objective of study is to see the process of influence of movie toward to student writing skill narrative text.

\section{THEORITICAL FRAME WORK}

Writing process is the stages a researcher produces something in its final written form, his process, of course, be affeted by the content of the writing.

Writing is a creative process of expressing ideas in the form of written language in a goal for example telling, convincing, or entertaining. (Dr.H.Dalman,M.pd.2018).

Movie is a type of entertainment. It is an art of audio visual storytelling. People in every part of the world watch movie and some people love it. A movie can be an interesting media for learning English. Teaching with movies is a powerful tool for developing positive characteristics and behaviors of young people. Chuchai (2016:523).

\section{The Benefits of movie}

1. Providing orientation and training or training for employes or new employes.

2. Showing training material and materials

3. Introducing new product and policies

4. Making information more standar (Dr. Benny A.pribadi,M.A.2017)

Narrative In a narrative text, a story is being told to the reader. It is a bit like a recount but it is usually a made up story. It usually has a number of events that take place and a problem that needs to be solved by the characters. It usually has a crisis in it and then is resolved at the end. An example of this is a fairytale. Based on perception in time, narration is the telling of a story that is the succession of events is given in chronological order. (Annisa rakhmi.2012).

From the definition above, it said that narrative text is a story tells us about something interesting that has purpose to amuse and to entertain for the readers or viewers. We used narrative when we tell a friend about something interesting that happen to us at work or at school and we tell someone a joke.

The purpose of a narrative report is to describe something. Many students write 
narrative reports thinking that these are college essays or papers. While the information in these reports is basic to other forms of writing, narrative reports lack the "higher order thinking" that essays requires.

The generic narrative text structure focuses on a series of proposed stages to build a story. In the narrative text the stage covers: orientation, complication of problem, resolution, and coda.

1.Orientation (Introduction) where character, setting, and story time are set. Usually answer which question? When? Where ? For example: Once upon a time, there was a wolf lived in the forest.

2.Complication or problem Telling the beginning of the problem that caused the crisis (climax). Complication usually involves the main character.

3.Resolution The end of the story is the solution of the problem. It needs a resolution of the problem. Problems can be solved can be better or worse, happy or sad. Sometimes there are some complications to be solved This adds and maintains interest and tension for its readers.

4.Reorientation / Coda Is a closing statement of the story and is optional. Can contain about moral lessons, suggestions or teachings from the author.

\section{METHODOLOGY OF RESEARCH}

This research is using study of literatur. study literatur is one of qualitatif research.

Literature study is carried out by studying and reviewing books that are related to the problem under study to obtain materials or sources of information about the problem under study. This technique is used not only to complement and strengthen the researcher's foundation in conducting research but also to complement the results of research that researchers do this technique is done by collecting various sources and literature (C) 2021, Tulip, Jurnal Tulisan Ilmiah Pendidikan. STKIPB ISSN: $2338-6162$ books relating to the problem being studied. By studying books relating to research, researchers are expected to be able to obtain data theoretically to support research.( Suarifki Diantama. 2018).

There are several kinds of sources of information used by researchers as material for literature study or literature study. Among them as follows: Research journals, research reports, abstracts, resource persons, books, newspapers or magazines internet. (Prof.H.M.Sukardi.2019)

There are no definite limits on how many books should be used as a reference, but there are instructions that give direction that the more books and sources of information support the exploration of literature study, the better and more beneficial for researchers.

(Prof.H.M.Sukardi.2019).

Qualitative research method is a research method based on the philosophy of post positivism or enter pretif, used to examine the condition of natural objects, where researchers are as key instruments, data collection techniques are carried out in triangulation. (Sugiyono. 2017)

\section{A. Technique of Collecting The Data Primary Data}

Primary data is data that is used as the main reference in this study. Sources used as primary data are:

\section{Book Source}

The book is used from 2010 until now. The book's Sources are used as follows:

Dalman.(2018) ketrampilan menulis. Depok :rajawali pers.

Pribadi,BennyA.(2017).Media\& tekhnologi dalam Pembelajaran,Jakarta:kencana.

Solahudi,Muhammad. (2017)Mahir writing tanpa repot. Editor Diyan Yulianto-cet.1yogyakarta laksana.

Rakhmi,Annisa(2012).Lets narrate a text! PT Balai pustaka (persero)

Wulandari.(2013) developing english skill (writing narrative texts).bandung :pakar raya. Diantama,Suarifqi.(2018).MetodePenelitianP 
endidikan. Bandung: PustakaRahmat.

Sukardi,Muhammad.(2019). Metodologi penelian Pendidikan kompetensi dan praktiknya.jakarta:Bumi Aksara.

Sugiyono.(2017). Metode Penelitian

Kualitatif. Bandung: Alfabeta,

\section{Secondary Data}

Secondary data is data that comes from other parties and has been prospected. The data is usually obtained from previous research documents or also called available data. Secondary data used in this study are:

a. Other scientific paper (script, thesis)

b. Journals.

Because of current situation with COVID19 , the campus suggests us to use literature study with data collecting, to avoid any virus spread among us.

\section{B. Technique of Collecting The Data}

Data analysis is the process of sistematically searching and compiling data obtained from interviews, field notes and documentation

(Sugiono 2017).

by organizing data into categories, describing it into units, synthesizing, composing into patterns, choosing which one are important and which will be studied, and making conclutions should be easily understood by yourself and others. qualitative data analysis is inductive, an analysis based on the data obtained, then developed into a hypothesis formulated based on the data is searched again and again so that it can be concluded that the hypothesis is accepted or rejected based on the data collected. If based on data that can be collected refeatedly with triangulation techniques, it turns out that the hypotesis is accepted, then the hypotesis develops into a theory.

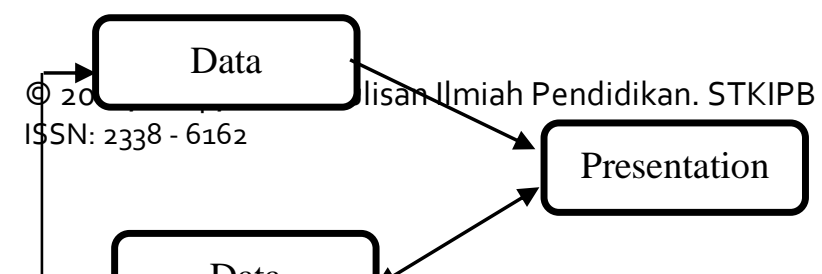

Data collection (Data collection) The main activity in each study is to collect data. In quantitative research data collection generally uses a questionnaire or a closed test. The data obtained is quantitative data. The data is then analyzed statistically. In qualitative research data collection by observation, in-depth interviews, and documentation or a combination of the three (triangulation). Data collection is carried out for days, maybe months, so that the data obtained will be a lot. In the initial stages, researchers conducted a general exploration of the social situation / object under study, everything that was seen and heard was all recorded. Thus researchers will obtain very much and very varied data.

Data reducation for that it is necessary to immediately conduct data analysis through data reduction. Reducing data means summarizing, choosing and choosing the main things, focusing on the important things, looking for themes and patterns. Thus the data that has been reduced will provide a clearer picture, and make it easier for researchers to do further data collection, and look for it if needed. Data reduction can be assisted with electronic equipment such as mini computers, by providing codes on certain aspects.

Conclusin verification The fourth step in qualitative data analysis according to Miles and Huberman is drawing conclusions and verification. The initial conclusions put forward are still temporary, and will change if no strong evidence is found to support the next stage of data collection. But if the conclusions raised at an early stage, supported by valid and consistent evidence when the researcher returns to the field to collect data. 


\section{Technique of Data}

The data validity teaching is triangulation. Triangulation is qualitative cross-validation. It assesses the sufficiency of the data according to the convergence of multiple data sources or multiple data collection procedures

(Sugiono) in the testing validity of the data, qualitative research methods have four data validity tests, there are Internal Validity, External validity dependability/ Rehabilitees Conformability / Objectivities.

\section{Conclusion}

Based on analysis and interpretion in the previous chapter, it can be conclued that process the influence of movie toward to student's writing skill narrative text. By using movie giving easy for student's to understand the lesson and the will get experience from that movie.

Movie can have any several functions they may have more than one the same time and it may include a movie for one purpose while your looks uses it another. movie is a type of visual communication which uses moving pictures and sound to tell story. the movie involves verbal, visual, and musical.

\section{Suggestion}

Based on the research result the writer gives some suggestion as follow ;

In teaching writing skill, the teacher is hoped more creative in teaching his student in order to maximize teaching learning process and does not make the student to be bored.

The teacher should be active to involve his student in teaching learning process

Movie media can be applied in english teaching learnig process, particularly the attempt of influence student's writing in narrative text.

\section{References}

Dalman.(2018) ketrampilan menulis. Depok :rajawali pers.

Susana,Ning. (2017) The social conflict in harrypotter and the order of the phoenix movie subtittle and its contribution in teaching drama( skripsi english education departemen faculty universitybof PGRI semarang.

Pribadi,Benny A.(2017).Media \& tekhnologi dalam pembelajaran.Jakarta:kencana.

Solahudi,Muhammad. (2017)Mahir writing tanpa repot. Editor Diyan Yulianto-cet. 1 yogyakarta laksana.

Rakhmi,Annisa(2012).Lets narrate a text! PT Balai pustaka (persero)

Wulandari.(2013) developing english skill (writing narrative texts).bandung :pakar raya.

Diantama,Suarifqi.(2018). Metode Penelitian Pendidikan.Bandung: Pustaka Rahmat.

Sukardi,Muhammad.(2019). Metodologi penelian Pendidikan kompetensi dan praktiknya.jakarta:Bumi Aksara.

Sugiyono. (2017). MetodePenelitian Kualitatif. Bandung: Alfabeta,

Laila fitrihan dayani the influence of using serial pictures toward students, narrative writing achievement ( scripsy english education department faculty of education and latters the state institute for islamic studies " sultan maulana hasanudin banten 2009. 
(C) 2021, Tulip, Jurnal Tulisan Ilmiah Pendidikan. STKIPB ISSN: $2338-6162$ 